\title{
CROP COEFFICIENT, DRY MATTER PARTITION AND SEEDLINGS QUALITY OF Hymenaea courbaril L. IN CONTAINERS SIZES UNDER WATER DEFICIT IRRIGATION ${ }^{1}$
}

\author{
César Antônio da Silva ${ }^{2 *}$, Durval Dourado $\mathrm{Neto}^{3}$ and Cícero José da Silva ${ }^{4}$
}

\begin{abstract}
${ }^{1}$ Received on 05.04.2014 accepted for publication on 28.11.2016.
${ }^{2}$ Instituto Federal Goiano, Campus Morrinhos, Morrinhos, GO - Brasil. E-mail: <cesar.antonio@ifgoiano.edu.br>. ${ }^{3}$ Universidade de São Paulo, Departamento de Produção Vegetal, Piracicaba, SP - Brasil. E-mail: <ddourado@usp.br> . ${ }^{4}$ Instituto Federal Goiano, Campus Morrinhos, Morrinhos, GO - Brasil. E-mail: <cicero.silva@ifgoiano.edu.br>. *Corresponding author.
\end{abstract}

\begin{abstract}
Native species seedlings are commonly used in the degraded areas reforestation, riparian forests and legal reserve. Among the factors that influence the seedlings quality, are the container size and the substrate water availability. Thus, the objective of this paper was to evaluate Hymenaea courbaril L. seedlings response in function of irrigation levels and container sizes. The experiment was carried out in greenhouse, in randomized blocks design, with three replications in split plots, in 2 x 5 scheme. Rigid pots of $3.1 \mathrm{~L}$ and stiff plastic tubes of $4.0 \mathrm{~L}$ were used in the plots, while irrigation levels equals to $20 \%, 40 \%, 60 \%, 80 \%$ and $100 \%$ of the maximum evapotranspiration (ETm) were used in the subplots. The stiff plastic tube provided larger ETm and increased seedlings quality and, consequently, larger crop coefficient $(\mathrm{Kc})$ in comparison with rigid pot, in the phase from 80 to 200 days after the sowing (DAS). The Kc of the seedlings in citrovase varired from 0.54 to 1.12 , of the planting at $200 \mathrm{DAS}$, according the Penman-Monteith methodology. Irrigation levels between ETm $86.8 \%$ and $100 \%$ propitiated larger seedlings quality index. To the 200 DAS, the roots dry matter was larger than the leaves dry matter, unlike the initial phases.
\end{abstract}

Keywords: Evapotranspiration; Dickson Quality Index; Water deficit.

\section{COEFICIENTE DE CULTIVO, PARTIÇÃO DE BIOMASSA E QUALIDADE DE MUDAS DE Hymenaea courbaril L. EM RECIPIENTES SOB IRRIGAÇÃO DEFICITÁRIA}

\begin{abstract}
RESUMO - Mudas de espécies nativas são comumente utilizadas no reflorestamento de áreas degradadas, matas ciliares e reserva legal. Dentre os fatores que influenciam na qualidade das mudas, estão o recipiente e a disponibilidade hídrica no substrato. Assim, o objetivo deste trabalho foi avaliar a resposta de mudas de Hymenaea courbaril L. em função de nivveis de irrigação e tamanhos de recipiente. O experimento foi conduzido em casa de vegetação, em blocos ao acaso, com três repetições em parcelas subdivididas, no esquema $2 \times 5$. Nas parcelas, utilizaram-se vasos de 3,1 L e citrovasos de 4,0 L, e nas subparcelas, niveis de irrigação iguais a 20\%, 40\%, 60\%, 80\% e 100\% da evapotranspiração máxima (ETm). O citrovaso proporcionou maior ETm e qualidade das mudas, em comparação ao vaso e, consequentemente, maior coeficiente de cultivo (Kc), na fase de 80 a 200 dias após a semeadura (DAS). O Kc das mudas em citrovaso variou de 0,54 a 1,12, do plantio a $200 \mathrm{DAS}$, conforme metodologia de Penman-Monteith. Niveis de irrigação de 86,8\% a $100 \%$ da ETm propiciaram mudas de maior índice de qualidade. Aos $200 \mathrm{DAS}$, a matéria seca de raizes foi maior que a de folhas, ao contrário das fases iniciais.
\end{abstract}

Palavras-chave: Evapotranspiração; Índice de Qualidade de Dickson; Déficit hídrico. 


\section{INTRODUCTION}

The need of degraded areas restoration and legal reserve composition in the areas of Brazilian Savana, Amazonian and Atlantic Forest Biomes increases the demand of native species seedlings, as the jatoba plant (Hymenaea courbaril L.).

The jatoba plant belongs to the Fabaceae family and it is found from Piaui State to the north Parana State, Brazil (Gonzaga et al., 2016), reaching, in the adult phase, from 10 to $15 \mathrm{~m}$ of height (Carvalho Filho et al., 2003). Due to the economic feasibility of jatoba plantations to the timber and food sectors (Costa et al., 2016) and their importance to reforestation, information about water requirement, container size and seedlings quality of this specie is necessary.

Several containers types were already used in the production of forest species seedlings, such as polyethylene sacks, rigid pots, bottles recycled made of polyethylene terephthalate (PET), and more recently, the tubettes and stiff plastic tubes made of rigid polyethylene (Silva et al., 2016). Nurseryman commonly uses tubettes, however $H$. courbaril L. demands larger containers(Carvalho Filho et al., 2003; Nascimento et al., 2011; Santos et al., 2011). in reason of its larger seed size and root system morphology.

Containers that restrict the root system growth are not suitable for the seedlings production of several species (Brachtvogel and Malavasi, 2010). They provide stress to the seedlings and photoassimilates accumulation in the roots, to the detriment of the aerial part (Samôr et al., 2002). The restriction at the root system, imposed by the substrate volume and by the container walls, reduces important parameters, as the height, foliar area (Vallone et al., 2010), stem diameter and dry matter production (Gasparin et al., 2014). Such reduction was observed in Anadenanthera macrocarpa seedlings (Benth.) Brenan and Sesbania virgata (Cav.) (Samôr et al., 2002).

Ferraz and Engel (2011) verified that containers of less volume reduce quality of $H$. courbaril seedlings. They concluded that tubettes of $300 \mathrm{~cm}^{3}$ originated seedlings with larger height and stem diameter, in comparison with seedlings produced in tubettes of 50 and of $110 \mathrm{~cm}^{3}$, enabling to reduce the seedlings production time in up to 70 days.

Besides the volume, dimensions and format of the container, the seedlings quality is function of the water availability. Not only the water deficit but also the water excess in the substrate are harmful in seedling's phase, according to its intensity and duration. The deficit reduces the nutrients absorption, while the excess leaches nutrients and it propitiates favorable conditions to pathogens (Lopes et al., 2005).

The stomatic closing, the reduction of perspiration and leaf area, the rapidity of the senescence and leaves abscission are prominent answers of the plants to the water deficit (Figueirôa et al., 2004). Leles et al. (1998) appraised three irrigation levels (daily irrigation, irrigation every seven days and irrigation every 15 days) in the production of $H$. courbaril seedlings, increasing the substrate moisture to the "field capacity moisture" after each irrigation level. To the 110 days after the sowing, the irrigation every seven days it increased the roots dry matter significantly, from 1.13 to $1.80 \mathrm{~g} \mathrm{seedling}^{-1}$, in comparison to the daily irrigation. On the other hand, Silva and Nogueira (2003) and Silva et al. (2008) verified that the increase of the water deficit causes larger proportion of roots dry matter/aerial part dry matter in woody species, such as E. contortisiliquum and $S$. terebinthifolius, respectively.

The study of morphologic characteristics isolatedly, such as seedling height (AM), stem diameter (DC), foliar area (AF), roots dry matter (MSR), among others, taking for instance the studies of Leles et al. (1998), Carvalho Filho et al. (2003) and Nascimento et al. (2011), they little support in the quality seedlings selection. Since there is always the possibility of the nurseryman to select seedlings of larger AM, discarding seedlings of larger vitality, larger DC and MSC, and smaller AF (Fonseca et al., 2002).

New researches are necessary, in the determination of seedlings quality indexes. One of most used indexes is the Dickson Quality Index (Dickson et al., 1960; Costa et al., 2012; Pinto Júnior et al., 2012), that it considers the distribution of seedlings dry matter. It is also primordial to determine the evapotranspirometric demand and Kc of native species in the initial growth phase, for a suitable irrigation management.

Like this, the objective of this work was to evaluate $\mathrm{Kc}$, the dry matter partition and the seedlings quality of $H$. courbaril L. in function of containers sizes under water deficit irrigation. 


\section{MATERIALAND METHODS}

The experiment was carried out in greenhouse at 561 m altitude, at $22^{\circ} 42^{\prime} 41^{\prime \prime}$ South latitude and $47^{\circ} 37^{\prime} 46^{\prime \prime}$ West longitude, in Piracicaba, São Paulo, Brazil. It began in September 2010 and ended in March 2011.

The substrate used was a mixture of $50 \%$ commercial Baseplant ${ }^{\circledR}$ substrate (consisting of $70 \%$ crushed and composted Pinus bark, $20 \%$ peat and $10 \%$ vermiculite) and $50 \%$ air dry thin sand based on volume. The chemical analyzes results of the mixture were: $\mathrm{pH}(\mathrm{CaCl} 2)=5.80$; Total carbon $=41.6 \mathrm{~g} \mathrm{dm}^{-3} ; \mathrm{N}=3.1 \mathrm{~g} \mathrm{dm}^{-3} ; \mathrm{P}_{2} \mathrm{O}_{5}=2.0$ $\mathrm{g} \mathrm{dm}^{-3} ; \mathrm{K}_{2} \mathrm{O}=0.7 \mathrm{~g} \mathrm{dm}^{-3} ; \mathrm{Ca}^{2+}=9.7 \mathrm{~g} \mathrm{dm}^{-3} ; \mathrm{Mg}^{2+}=1.2$ $\mathrm{g} \mathrm{dm}^{-3} ; \mathrm{S}=0.3 \mathrm{~g} \mathrm{dm}^{-3} ; \mathrm{Cu}=7.0 \mathrm{mg} \mathrm{kg}^{-1} ; \mathrm{Mn}=85.0 \mathrm{mg}$ $\mathrm{kg}^{-1} ; \mathrm{Zn}=20.0 \mathrm{mg} \mathrm{kg}^{-1} ; \mathrm{Fe}=6498.0 \mathrm{mg} \mathrm{kg}^{-1} ; \mathrm{B}=3.0 \mathrm{mg}$ $\mathrm{kg}^{-1}$; and $\mathrm{Na}=499.0 \mathrm{mg} \mathrm{kg}^{-1}$, dry basis $\left(60-65^{\circ} \mathrm{C}\right)$. The physical analyzes the mixture presented: substrate density $=1.02 \mathrm{~g} \mathrm{~cm}^{-3}$; particle density $=2.44 \mathrm{~g} \mathrm{~cm}^{-3}$; total sand $=859 \mathrm{~g} \mathrm{~kg}^{-1}$; Silt $=28 \mathrm{~g} \mathrm{~kg}^{-1}$; Clay $=113 \mathrm{~g} \mathrm{~kg}^{-1}$; and moisture in the "field capacity" (by Richards extractor) $=0.262 \mathrm{~cm}^{3} \mathrm{~cm}^{-3}$. For each $100 \mathrm{~L}$ of the mixture, 200 $\mathrm{g}$ of the 20-11-15 fertilizer $\left(\mathrm{N}-\mathrm{P}_{2} \mathrm{O}_{5}-\mathrm{K}_{2} \mathrm{O}\right)$ and $15 \mathrm{~L}$ of vermiculite were added.

Jatoba plant seeds were selected, eliminating them in a flattened form and of mass less than $3.0 \mathrm{~g}$, being obtained a batch of 400 seeds, with mass of $2325 \mathrm{~g}$. The seeds were scarified with metallic sandpaper and immersed in water at room temperature for 24 hours, according to Azerêdo et al. (2003). Then, the seeds were treated with carbendazim $\left(150 \mathrm{~g} \mathrm{~L}^{-1}\right)+$ Thiram $\mathbb{R}$ (350 $\mathrm{g} \mathrm{L}^{-1}$ ) fungicide, using $6.0 \mathrm{~mL}$ of the commercial product per $\mathrm{kg}$ of seeds. The sowing was done in plastic cups of $300 \mathrm{~mL}$, drilled in the base and filled with substrate. At 30 days after sowing (DAS), uniform seedlings with the first pair of open leaves were planted in containers under greenhouse conditions.

The experimental design was a randomized complete block with three replications, in split plots, in the 2 $x 5$ scheme. Two containers sizes were used in the plots, made of polypropylene: rigid pot (vase) of $3.1 \mathrm{~L}$ and

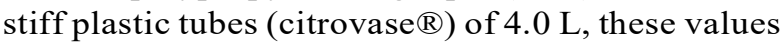
equivalent to the substrate content; and in the subplots, five irrigation levels, equals to $20 \%, 40 \%, 60 \%, 80 \%$ and $100 \%$ of maximum evapotranspiration (ETm) were applied. Each subplot was constituted by eight seedlings. The rigid pots were $19.0 \mathrm{~cm}$ in diameter at the upper border, $15.0 \mathrm{~cm}$ in diameter at the base and $15.0 \mathrm{~cm}$ in height, while the stiff plastic tubes measured 14.0 $\mathrm{cm}$ in diameter, $10.2 \mathrm{~cm}$ in diameter at the base and $35.5 \mathrm{~cm}$ high.

The drip irrigation system presented selfcompensating emitters of 2.0 and $4.0 \mathrm{~L} \mathrm{~h}^{-1}$, being used in different combinations of adapters with 2 and 4 outputs to obtain water flows $\left(0.5,1.0,1.5,2.0\right.$ and $\left.2.5 \mathrm{~L} \mathrm{~h}^{-1}\right)$ equivalent to irrigation levels. The irrigation levels were applied daily, starting at 35 DAS. The seedlings maximum evapotranspiration (ETm), in mm, was measured according to equation 1 :

$$
\mathrm{ETm}=\frac{40 \cdot\left(\mathrm{M}_{\theta \mathrm{cc}}-\mathrm{M}_{\theta \mathrm{current}}\right)}{\rho_{a} \cdot \pi \cdot \mathrm{D}^{2}}
$$

where: $\mathrm{M}_{\theta \mathrm{cc}}$ is the mass of the container + seedling + substrate with moisture in the "field capacity" (g); $\mathrm{M}_{\theta \text { current }}$ is the mass of the container + seedling + substrate with current moisture obtained at the end of the day, before irrigation $(\mathrm{g}) ; \rho_{\mathrm{a}}$ is the water specific mass $(\mathrm{g}$ $\mathrm{cm}^{-3}$ ) at room temperature; $\mathrm{D}$ is the diameter of the container upper edge $(\mathrm{cm})$ at the substrate level.

The "field capacity" moisture was measured in three additional pots of each container type, according to the Casaroli and Jong van Lier (2008) methodology: coating the base of the containers with geotextile fabric; packaging of substrate in containers; Immersion of the containers in water until half their height; substrate saturation by means of capillarity; sealing of the substrate surface with plastic canvas and adhesive tape to prevent evaporation; drainage of substrate water excess; measure the water mass $(\mathrm{Ma})$ retention on the substrate after drainage. Through the equation 2, the "field capacity moisture" based on volume $\left(\theta_{\text {cc }}\right)$ was obtained, which presented in the containers the mean value of 0.38 $\mathrm{cm}^{3} \mathrm{~cm}^{-3}$ :

$$
\theta_{\mathrm{cc}}=\frac{\mathrm{V}_{\mathrm{a}}}{\mathrm{V}} \therefore \theta_{\mathrm{cc}}=\frac{\mathrm{d}_{\mathrm{s}} \cdot \mathrm{M}_{\mathrm{a}}}{\rho_{\mathrm{a}} \cdot \mathrm{M}_{\mathrm{s}}}
$$

where: $\mathrm{V}_{\mathrm{a}}, \mathrm{M}_{\mathrm{a}}$ and $\rho_{\mathrm{a}}$ are the volume $\left(\mathrm{cm}^{3}\right)$, the mass $(\mathrm{g})$ and the specific mass of water $\left(\mathrm{g} \mathrm{cm}^{-3}\right)$, retained on the substrate after the drainage; $M_{\mathrm{s}}$ is the dry substrate mass $(\mathrm{g}) ; \mathrm{V}$ and $\mathrm{d}_{\mathrm{s}}$ are the volume $\left(\mathrm{cm}^{3}\right)$ and the substrate density in the containers $\left(\mathrm{g} \mathrm{cm}^{-3}\right)$, respectively.

The mass difference $\left(\mathrm{M} \theta_{\mathrm{cc}}-\mathrm{M} \theta_{\text {current }}\right)$ was measured daily, in three additional pots of each container type, by means of weighing-machine with capacity of 10,000 
$\mathrm{g}$ and accuracy of $1.0 \mathrm{~g}$. After weighing, the evapotranspired water mass was replaced, returning the substrate to $\theta \mathrm{cc}$.

Growth fertilizers were applied conventionally, supplying per seedling: $1.0 \mathrm{~g}$ ammonium sulfate, at 45 and 140 DAS, and 1.0 g fertilizer 20-11-15+ micronutrients were applied at 75 DAS. The temperature and relative air humidity were recorded in a datalogger, installed at $2.0 \mathrm{~m}$ height, inside the greenhouse, while evapotranspiration was obtained by weighing the seedlings (Figure 1).

The crop coefficient (Kc) was estimated in five phases: from the planting in the containers at 40 DAS, from 40-80, 80-120, 120-160 and from 160-200 DAS, according to two methods (Equations 3 and 4): ETo estimated by the Penman-Monteith equation, in greenhouse environment, considering the minimum wind speed value $\left(0.5 \mathrm{~m} \mathrm{~s}^{-1}\right)$ proposed in the FAO / 56 Bulletin (Allen et al., 1998); and the ETo obtained through class A pan, equivalent to the evaporation product $\left(\mathrm{EV}, \mathrm{mm} \mathrm{dia}^{-1}\right)$ by the class A pan coefficient $(\mathrm{Kp})$ :

$$
\begin{aligned}
& \mathrm{Kc}_{(\text {Penman-Monteith) }}=\frac{\mathrm{ETc}}{\mathrm{ETo}} \\
& \mathrm{Kc}_{(\mathrm{Pan})}=\frac{\mathrm{ETc}}{\mathrm{EV} \cdot \mathrm{Kp}}
\end{aligned}
$$

where: $\mathrm{Kc}_{\text {(Penman-Monteith) }}$ is the crop coefficient, based on the Penman-Monteith methodology, standardized by the FAO; $\mathrm{Kc}_{\text {(Pan) }}$ is the crop coefficient in function of evaporation in the class A pan; ETc is the seedlings evapotranspiration $\left(\mathrm{mm} \mathrm{day}^{-1}\right)$, without water restriction; and ETo is the reference evapotranspiration $\left(\mathrm{mm} \mathrm{day}^{-1}\right)$.

The class A pan coefficient (Kp) was estimated by equation 5, from Cuenca (1989), considered by Sentelhas and Folegatti (2003), the one that presents the highest correlation with Penman-Monteith in the estimation of Kp, in Piracicaba, SP, Brazil.

$$
\begin{aligned}
& \mathrm{Kp}=0,475-2,4 \cdot 10^{-4} \mathrm{U}_{2}+5,16 \cdot 10^{-3} \mathrm{UR}+ \\
& 1,18 \cdot 10^{-3} \mathrm{~B}-1,6 \cdot 10^{-5} \mathrm{UR}^{2}-1,01 \cdot 10^{-6} \mathrm{~B}^{2}- \\
& 8,0.10^{-9} \mathrm{UR}^{2} \mathrm{U}_{2}-1,0.10^{-8} \mathrm{UR}^{2} \mathrm{~B}
\end{aligned}
$$

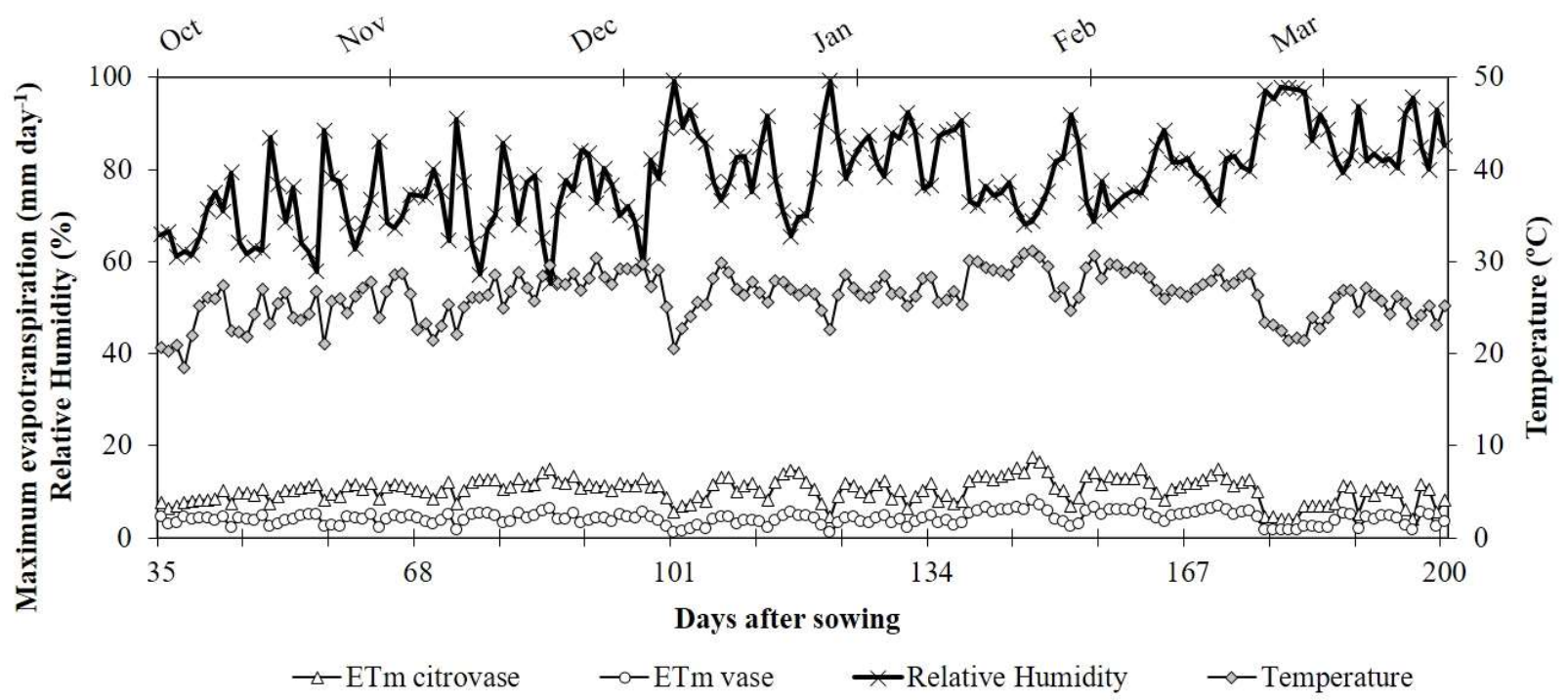

Figure 1 - Daily average values of temperature, relative humidity and maximum evapotranspiration (ETm) of H. courbaril L. seedlings, in function of containers, in the period from 35 to 200 days after sowing, in the greenhouse, in Piracicaba, SP.

Figura 1 - Valores médios diários de temperatura, umidade relativa do ar e evapotranspiração máxima (ETm) de mudas de jatobazeiro, em função de recipientes, no período de 35 a 200 dias após semeadura, em casa de vegetação, em Piracicaba, SP. 
where: $U_{2}$ is the wind speed, two meters height $\left(\mathrm{km} \mathrm{day}^{-1}\right)$; UR is the average relative humidity $(\%)$; and $\mathrm{B}$ is the boundary length surrounding the pan (m).

The seedlings quality was evaluated at 120,160 and 200 DAS, using the equation 6 , described by Dickson et al. (1960):

$$
\mathrm{IQD}=\frac{\mathrm{MSM}}{\frac{\mathrm{AM}}{\mathrm{DC}}+\frac{\mathrm{MSPA}}{\mathrm{MSR}}}
$$

where: IQD is the Dickson quality index (dimensionless); MSM is the seedling dry matter mass (g); AM is the seedling height (cm); DC is the stem diameter ( $\mathrm{mm})$; MSPA is the aerial part dry matter mass (g); and MSR is the roots dry matter mass (g).

The percentage of dry matter of roots, stem and leaves, which composed the seedlings total dry matter, were also measured at 120, 160 and 200 DAS.

\section{RESULTS}

The Kc values of $H$. courbaril L. were lower in the planting phases until 120 days after sowing, not differing from each other, and higher in the phases of 120-160 and 160-200 DAS, by the Tukey test, at 0.05 significance level (Figure 2). On the other hand, in the citrovase, greater Kc were estimated in the phases of 80-120 and 120-160 DAS, and a reduction in Kc values in the period 160-200 DAS was observed, certainly due to the physical limitation imposed by the container walls and the volume of substrate irrigated to supply $100 \%$ of ETm is not sufficient to meet the seedlings evapotranspirometric demand in the last phase.

Comparing the containers, Kc of the seedlings was upper in the citrovase, mainly in the phases of 80-120, 120-160 and 160-200 DAS, regardless of the ETo determination methodology (Penman-Monteith or Class A pan).

In relation to the dry matter partition, comparing irrigation levels inside the containers, higher values of MSR, MSC and MSF were observed in irrigation levels of $100 \%, 80 \%$ and $60 \%$ of ETm in both containers (Figure 3). The seedlings presented, on average, a larger development in the citrovase, due to the greater evapotranspiration and water reposition in this container. At 120 DAS, irrigation levels of $40 \%, 60 \%, 80 \%$ and
$100 \%$ of the ETm provided higher MSR, MSC and MSF in the citrovase, in comparison to the vase, while in the most severe water deficit ( $20 \%$ level), there was no significant difference among containers in the MSR and MSC.

Jatoba seedlings showed higher leaf dry matter (MSF) than roots (MSR) and stem (MSC) in all treatments at 120 and 160 DAS. In older seedlings with 200 DAS, a reduction in the proportion of MSF and increase in the fraction of MSR were observed in relation to the two initial phases.

Comparing stem and root system development, at $120 \mathrm{DAS}$, the seedlings had a higher stem dry matter (MSC) than roots dry matter (MSR), while at 200 DAS, MSR values were higher than MSC, in most of the treatments. Among treatments, there was no significant interaction of containers $\mathrm{x}$ irrigation levels in MSF, at 160 DAS, and in MSF and MSC, at 200 DAS.

At 200 DAS, there was a significant interaction of containers and irrigation levels only in the MSR, where the seedlings coming from citrovase under water regimes $80 \%$ and $100 \%$ presented the highest values of MSR.

The Dickson quality index (IQD) of the H. courbaril L. seedlings presented a linear response in the seedlings from pots and, quadratic response, in the seedlings from citrovases, as a function of irrigation levels (Figure 4).

In the seedlings grown in pots, the highest IQDs were $0.70,2.00$ and 3.16 at 120,160 and 200 DAS, in the absence of water deficit, whereas in the seedlings originating in citrovases, they were 1.95, 2.69 and 4.17, estimated with irrigation levels of $95.6 \%, 86.8 \%$ and $87.9 \%$ of ETm, respectively at these ages.

Concerning the containers, the citrovase provided a higher quality of the seedlings, compared to the pot, at all ages and irrigation levels, except for 20\% (Table 1).

\section{DISCUSSION}

The Kc of jatoba seedlings ranged from 0.55 to 1.12 by the FAO / 56 standard method of PenmanMonteith, values lower than those obtained with the Class A pan methodology. It is possible that the "Class A" pan methodology is not the most suitable for the estimation of ETo in greenhouse, since the determination of this depends on $\mathrm{Kp}$ (Allen et al., 1998), which according to Peixoto et al. (2014) is influenced by soil cover, border

Revista Árvore. 2017;41(2):e410213 

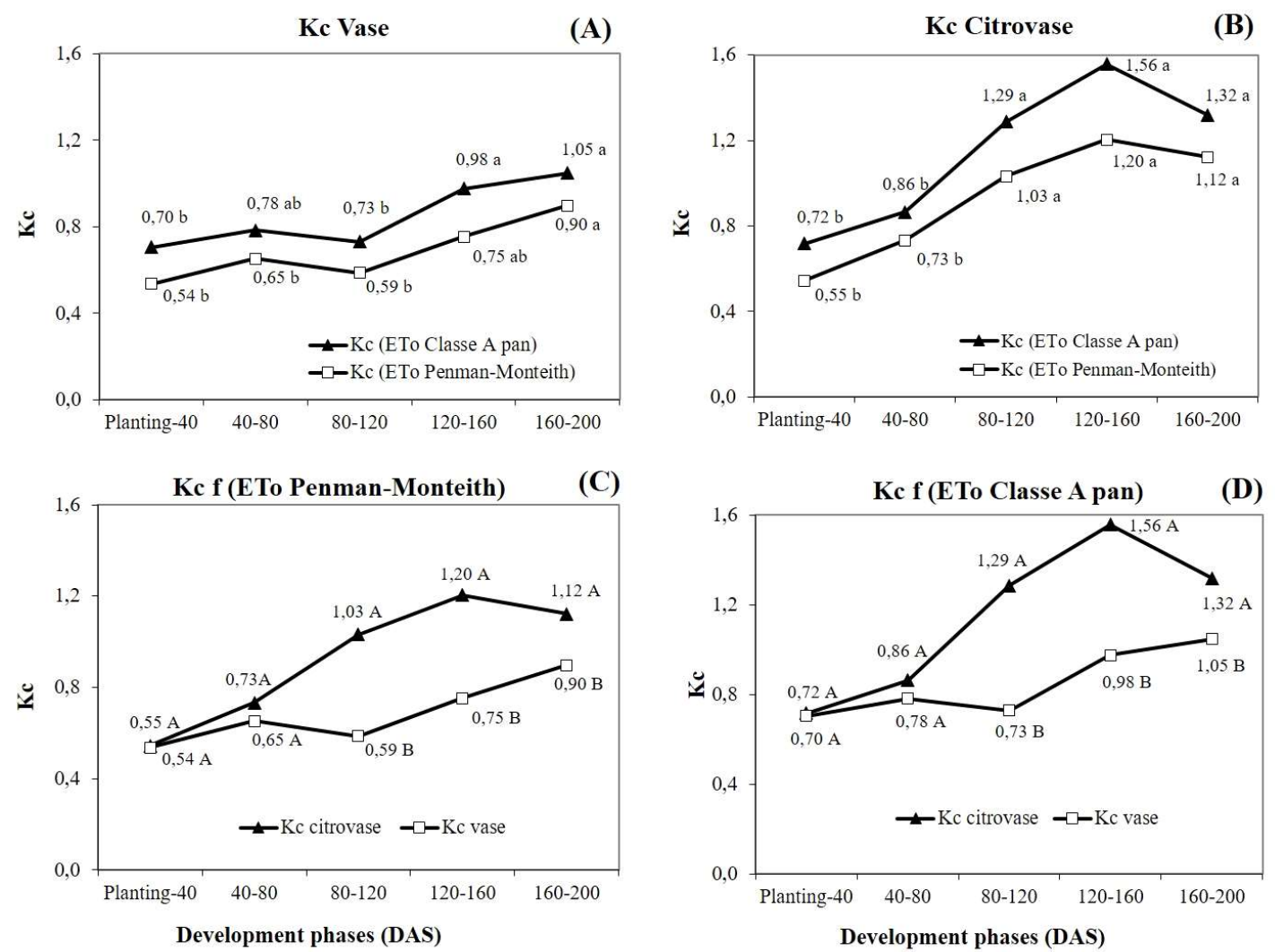

Averages followed by the same lowercase letter, for each ETo estimation methodology, do not differ among the development phases, by Tukey test, at $5 \%$ probability. And averages followed by the same capital letter, for each development phase, do not differ between containers, by the Tukey test, at $5 \%$ probability.

Figure 2 - Crop coefficient (Kc) of $H$. courbaril L. seedling, in function of containers (A and B), of ETo estimate methodology (C and D) and in function of seedlings development phases, in Piracicaba, SP.

Figura 2 - Coeficiente de cultivo (Kc) do jatobazeiro, em função de recipientes ( $A$ e B), de metodologias de cálculo da ETo (C e D) e de fases de desenvolvimento das mudas, em Piracicaba, SP.

extension with or without vegetation, and environmental conditions such as wind and relative humidity.

In the conditions of this work, the "Class A" pan was surrounded by a soil area without vegetation, with a surrounding of $1.0 \mathrm{~m}$ and low wind speed. Considering the equation proposed by Cuenca (1989), it is probable that the absence of some parameters in the equation underestimated the values of $\mathrm{Kp}$ and ETo, in relation to the ETo equation of Penman-Monteith, which considers in addition to these parameters, the balance of radiation and the air temperature, making the ETo values higher and Kc values lower.

The highest values of $\mathrm{Kc}$ in the citrovase, in relation to the pot, depend mainly on the dimensions of the containers, especially the height. This superiority in Kc, up to $74.5 \%$ by the Penman-Monteith methodology, and up to $76.7 \%$ by the "Class A" pan methodology, in the 80 to 120 DAS phase, is certainly due to the lower physical walls limitation and bottom of the citrovase to the root system as compared to the pot.

From planting up to $80 \mathrm{DAS}$, there was no statistical difference of Kc between the containers, however, from 80 to 200 DAS, higher Kc values were obtained in the citrovase. This is due, above all, to the greater mass of the root system and leaf area of the seedlings in this container, which, according to Pereira and Allen (1997), contribute to the increase of ETm and consequently of Kc. On the other hand, in containers of smaller substrate volume, such as the rigid pot, the seedlings did not have sufficient water for maximum 

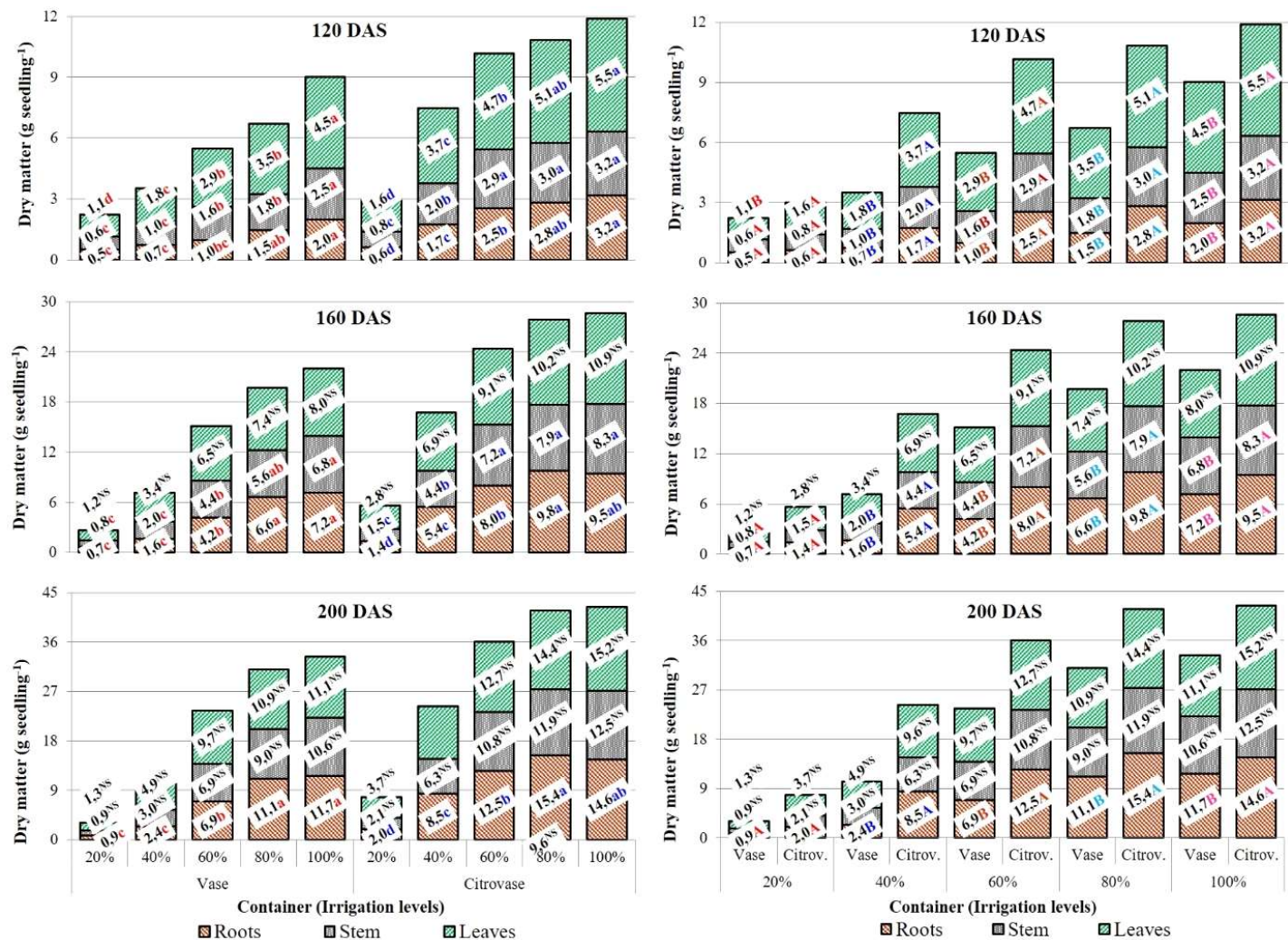

Averages followed by the same letter, lowercase for irrigation levels within container (left charts), and uppercase for containers within irrigation levels (right charts) for each organ (roots, stem and leaves) do not differ from each other, at 5\% probability, by the Tukey test; NS - nonsignificant interaction

Figure 3 - Partition of dry matter (roots, stem and leaves) of $H$. courbaril L. seedlings, to the 120 , 160 and 200 days after sowing (DAS), in function of containers and irrigation levels (\% ETm), in Piracicaba, SP.

Figura 3-Partição da matéria seca (raízes, caule e folhas) de mudas de jatobazeiro, aos 120 , 160 e 200 dias após semeadura $(D A S)$, em função de recipientes e níveis de irrigação (\% ETm), em Piracicaba, SP.
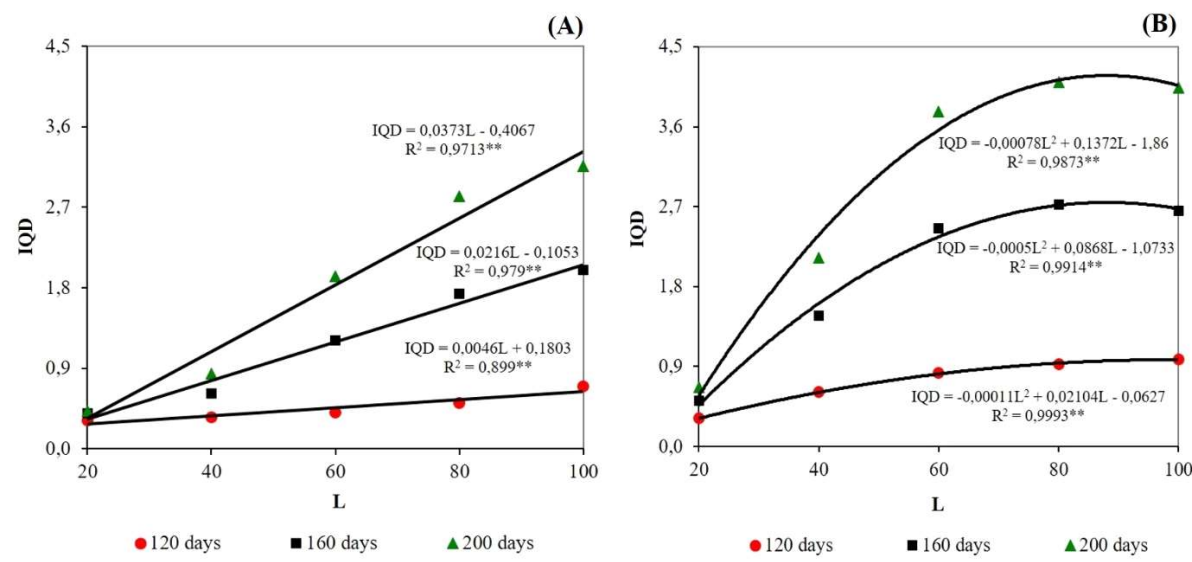

Figure 4 - Dickson's Quality Index (IQD) of H. courbaril L. seedlings, in vase (A) and citrovase (B), in function of irrigation levels (L, \% ETm) and days after sowing, in Piracicaba, SP.

Figura 4 - Índice de qualidade de Dickson (IQD) de mudas de jatobazeiro em vaso (A) e citrovaso (B), em função de níveis de irrigação (L, \% ETm) e dias após semeadura, em Piracicaba, SP. 
Table 1 - Dickson's Quality Index (IQD) of $H$. courbaril L. seedlings, in function of age (days after sowing), containers and irrigation levels, in Piracicaba, SP.

Tabela 1 - Índice de qualidade de Dickson de mudas de jatobazeiro, em função da idade (dias após semeadura), recipientes e níveis de irrigação, em Piracicaba - SP.

\begin{tabular}{|c|c|c|c|c|c|c|c|c|}
\hline \multirow[t]{2}{*}{ Age } & \multirow[t]{2}{*}{ Container } & \multicolumn{5}{|c|}{ Irrigation level (\% ETm) } & \multirow[t]{2}{*}{ Average } & \multirow[t]{2}{*}{ DMS } \\
\hline & & 20 & 40 & 60 & 80 & 100 & & \\
\hline \multirow{3}{*}{120 days } & Citrovase & 0,31 a & $0,61 \mathrm{a}$ & $0,82 \mathrm{a}$ & 0,93 a & 0,98 a & 0,73 & \multirow{3}{*}{0,13} \\
\hline & Vase & $0,32 \mathrm{a}$ & $0,35 \mathrm{~b}$ & $0,41 \mathrm{~b}$ & $0,51 \mathrm{~b}$ & $0,70 \mathrm{~b}$ & 0,46 & \\
\hline & Average: & 0,32 & 0,48 & 0,62 & 0,72 & 0,84 & 0,59 & \\
\hline \multirow{3}{*}{160 days } & Citrovase & $0,52 \mathrm{a}$ & $1,47 \mathrm{a}$ & $2,46 \mathrm{a}$ & $2,72 \mathrm{a}$ & $2,66 \mathrm{a}$ & 1,96 & \multirow{3}{*}{0,25} \\
\hline & Vase & $0,40 \mathrm{a}$ & $0,62 \mathrm{~b}$ & $1,21 \mathrm{~b}$ & $1,73 \mathrm{~b}$ & $2,00 \mathrm{~b}$ & 1,19 & \\
\hline & Average: & 0,46 & 1,04 & 1,83 & 2,22 & 2,33 & 1,58 & \\
\hline \multirow{3}{*}{200 days } & Citrovase & 0,66 a & 2,13 a & 3,77 a & $4,10 \mathrm{a}$ & $4,04 \mathrm{a}$ & 2,94 & \multirow{3}{*}{0,49} \\
\hline & Vase & $0,42 \mathrm{a}$ & $0,84 \mathrm{~b}$ & $1,93 \mathrm{~b}$ & $2,82 \mathrm{~b}$ & $3,16 \mathrm{~b}$ & 1,83 & \\
\hline & Average: & 0,54 & 1,48 & 2,85 & 3,46 & 3,60 & 2,39 & \\
\hline
\end{tabular}

Averages followed by the same letter in column, for the same age, do not differ among themselves, by the Tukey test, at $5 \%$ probability. DMS: Significant Minimum Difference

transpiration during part of the day, even if the substrate had been irrigated daily, to return it to the moisture in "field capacity".

In the 160 to 200 DAS phase, there was a decrease in the Kc of the citrovase seedlings, probably due to the winding and root death in the bottom of the container, due to the accumulation of salts leached to the base, by the wetting front advance. Another factor that may have caused decrease in Kc at this stage of the seedlings was the physical limitation imposed by the bottom of the container. Consequently, there was a reduction in water absorption, lower ETm and Kc.

The MSC and MSF values obtained in this study differ from those found by Nascimento et al. (2011). In the present study, the total dry matter content (18.6 g) was higher in MSC (7.2 g) and lower MSF $(6.1 \mathrm{~g})$ in jatoba plants irrigated at è $\mathrm{cc}_{\mathrm{cc}} 100 \%$, at 155 days of age, while in this work the largest dry matter fraction was composed of leaves, in all the treatments, regardless of the seedlings age. These differences are possibly due to the environmental conditions in which the researches were carried out, since Nascimento et al. (2011) used sandy loam soil (79\% sand) and conducted the work in the state of Pernambuco, Brazil, where the average temperature is higher. Even when irrigating $100 \%$ of field capacity in sandy loam soil with low water retention, the seedlings may have presented higher water stress, greater stomatal closure and greater accumulation of photoassimilates in the stem, to the detriment of leaves. Consequently, there was lower leaf production (MSF) and higher stem dry matter (MSC), compared to $100 \%$ ETm replacement in this work.

The seedlings grown in pots showed greater water deficiency than those grown in citrovase, even increasing the moisture of the substrate to "field capacity" daily. The greatest water deficit in the pot is mainly due to the lower volume of substrate in this container, causing water deficit at certain times of the day and, consequently, lower MSF values, leaf area and evapotranspiration. The results of this work are consistent with those obtained by Brachtvogel and Malavasi (2010), regarding the physical limitation imposed by the container size. These authors, working with three containers volumes (tubettes of 100 and $180 \mathrm{~cm}^{3}$ and plastic bag of $10 \mathrm{x}$ $15 \mathrm{~cm}$ ), verified a decrease in the height, stem diameter and dry matter of the aerial part and total, of seedlings of Peltophorum dubium (Sprengel) Taubert (Caesalpinioideae) in the smaller containers.

The substrate water restriction, mainly in the $20 \%$ and $40 \%$ ETm replenishments, reduces the sap flow, as well as leaf water potential, turgescence and foliar gas exchange, causing a decrease in $\mathrm{CO}_{2}$ assimilation, as observed by Rocha et al. (2016), by suspending the irrigation for 15 days in guanandi (Calophyllum brasilense Cambess), African mahogany (Khayaivorensis A. Chev) and oiti (Licania tomentosa Benth Fritsch) seedlings. Consequently, the growth and dry matter of different seedlings vegetative organs are lower, causing, according to Nascimento et al. (2011), lower leaf mass and leaf area, and less translocation of photoassimilates to the new growing cells. 
According to the IQD equation, proposed by Dickson et al. (1960), the two characteristics that most influenced the quality of $H$. courbaril L. seedlings were MSR and MSM, while higher values of seedling height (AM) and shoot dry matter mass (MSPA) reduce the IQD.

The IQD is also a function of stem diameter (DC). This parameter presented higher values in containers of larger dimensions, as in the studies_of Carvalho et al. (2003) and Silva et al. (2016), which obtained, on average, higher DC of jatoba seedlings in $15 \times 20$ $\mathrm{cm}$ plastic bag (under shaded screen $50 \%$, using the substrate composed of soil + sand 1:1) and citrovase of $35.5 \mathrm{~cm}$ of height $x 12.1 \mathrm{~cm}$ of mean diameter, respectively, compared to smaller containers. When studying the correlation of eight growth parameters with the IQD in seedlings of Eucalyptus grandis and Pinus elliottii var. Elliottii, Binotto et al. (2010) concluded that the dry matter (roots, total and aerial part), followed by $\mathrm{DC}$, are the variables with the highest correlation with IQD, highlighting the importance of these parameters in the seedlings quality. On the other hand, seedling height and number of leaves present low correlation with IQD.

At the end of the experiment, irrigation levels from $87.9 \%$ to $100 \%$ ETm provided higher seedling quality. However, species such as Euterpe oleraceae Mart. presented better quality seedlings using a drip irrigation level equal to $130 \%$ of the moisture in the field capacity, when produced in $15 \times 25 \mathrm{~cm}$ polyethylene bags (Silvestre et al., 2016).

Citrovase was the most suitable container to the development of jatoba seedlings, increasing the MSR / MSPA ratio, a feature that, according to Lima et al. (2006), favors the survival of seedlings in the field. According to these authors, too narrow containers, of small diameter, causes the roots have down, not growing laterally after the transplanting. However, the lateral roots growth was favored by the longitudinal grooves in the citrovase walls, increasing the roots dry matter.

\section{CONCLUSIONS}

1. The Kc of the seedlings was larger in the citrovase than in the vase, in the period from 80 to 200 days after sowing, due to the higher height and volume of the citrovase and less physical limitation imposed by the bottom of this container.
2. At $200 \mathrm{DAS}$, the seedlings presented higher roots dry matter, and lower leaves dry matter, compared to the initial phases.

3. The citrovase originated $H$. courbaril L. seedlings of better quality in relation to the pot, under irrigation levels of 86.8 to $100 \%$ ETm.

\section{REFERENCES}

Allen RG, Pereira LS, Raes D, Smith M. Crop evapotranspiration: guidelines for computing crop water requirements. Rome: FAO; 1998. 300 p. (Irrigation and Drainage Paper, 56).

Azerêdo GA, Bruno RLA, Andrade LA, Cunha AO. Germinação em sementes de espécies florestais da Mata Atlântica (Leguminoseae) sob condições de casa de vegetação. Pesquisa Agropecuária Tropical. 2003;33:11-6.

Binotto AF, Lúcio AD, Lopes SJ. Correlations between growth variables and the dickson quality índex in forest seedlings. Cerne. 2010;16:457-64.

Brachtvogel EL, Malavasi UC. Volume do recipiente, adubação e sua forma de mistura ao substrato no crescimento inicial de Peltophorum dubium (sprengel) taubert em viveiro. Revista Árvore. 2010;34:223-32.

Carvalho Filho JLS, Arrigoni-Blank MF, Blank AF, Rangel MSA. Produção de mudas de jatobá (Hymenaea courbaril L.) em diferentes ambientes, recipientes e composições de substratos. Cerne. 2003;9:109-18.

Casaroli D, Jong van Lier Q. Critérios para a determinação da capacidade de vaso. Revista Brasileira de Ciencia do Solo. 2008;32:59-66.

Costa CB, Souza AL, Castelanni DC, Silva ML, Borges EEL. Análise de viabilidade da produção de semente e polpa de jatobá (Hymenaea spp) na região sul de Goiás. Ciência Florestal. 2016;26:1023-36.

Costa E, Oliveira LC, Espírito Santo TL, Leal PAM. Production of baruzeiro seedling in different protected environments and substrates. Engenharia Agrícola. 2012;32:633-41.

Cuenca RH. Irrigation system design: an engineering approach. New Jersey: Prentice-Hall; 1989.

Revista Árvore. 2017;41(2):e410213 
Dickson A, Leaf AL, Hosner JF. Quality appraisal of white spruce and white pine seedling stock in nurseries. The Forestry Chronicle. 1960;36:10-3.

Ferraz AV, Engel VL. Efeito do tamanho de tubetes na qualidade de mudas de jatobá (Hymenaea courbaril L. var. stilbocarpa (Hayne) Lee et Lang.), ipê-amarelo (Tabebuia chrysotricha (Mart. ex DC.) Sandl.) e guarucaia (Parapiptadenia rigida (Benth.) Brenan. Revista Árvore. 2011;35:413-23.

Figueirôa JM, Barbosa DCA, Simabukuro EA. Crescimento de plantas jovens de Myracrodruon urundeuva Allemão (Anacardiaceae) sob diferentes regimes hídricos. Acta Botânica Brasileira. 2004;18:573-80.

Fonseca EP, Valéri SV, Miglioranza É, Fonseca NAN, Couto L. Padrão de qualidade de mudas de Trema micrantha (L.) Blume, produzidas sob diferentes períodos de sombreamento. Revista Árvore. 2002;26:515-23.

Gasparin E, Avila AL, Araujo MM, Cargnelutti Filho A, Dorneles DU, Foltz DRB. Influência do substrato e do volume de recipiente na qualidade das mudas de Cabralea canjerana (Vell.) Mart. em viveiro e no campo. Ciência Florestal. 2014;24:553-63.

Gonzaga LM, Silva SS, Campos SA, Ferreira RP, Campos ANR, Cunha ACMCM. Evaluation of substrates and amf sporulation in the production of seedlings of native forest species. Revista Árvore. 2016;40:245-54.

Leles PSS, Carneiro JGA, Barroso DG. Comportamento de mudas de Hymenaea courbaril L. var stilbocarpa (Hayne) e Apuleia leiocarpa (Vog.) Macbr. produzidas sob três regimes de irrigação. Revista Árvore. 1998;22:11-9.

Lima RLS, Severino LS, Silva MIL, Vale LS, Beltrão NEM. Volume de recipientes e composição de substratos para produção de mudas de mamoneira. Ciência e Agrotecnologia. 2006;30:480-6.

Lopes JLW, Guerrini IA, Saad JCC, Silva MR. Efeitos da irrigação na sobrevivência, transpiração e no teor relativo de água na folha em mudas de Eucalyptus grandis em diferentes substratos. Scientia Forestalis. 2005;68:97-106.
Nascimento HHC, Nogueira RJMC, Silva EC, Silva MA. Análise do crescimento de mudas de jatobá (Hymenaea courbaril L.) em diferentes níveis de água no solo. Revista Árvore. 2011;35:617-26.

Peixoto TDC, Levien SLA, Bezerra AHF, Espínola Sobrinho J. Avaliação de diferentes metodologias de estimativa da ETo baseadas no tanque Classe A, em Mossoró, RN. Revista Caatinga. 2014;27:58-65.

Pereira LS, Allen RG. Novas aproximações aos coeficientes culturais. Engenharia Agrícola, 1997;16:118-43.

Pinto Júnior AS, Guimarães VF, Dranski JAL, Steiner F, Malavasi MM, Malavasi UC. Armazenamento de sementes de pinhão manso em diferentes embalagens e ambientes. Revista Brasileira de Sementes. 2012;34:636-43.

Rocha MAM, Lacerda CF, Bezerra MA, Barbosa FEL, Feitosa HO, Sousa CHC. Physiological responses of three woody species seedlings under water stress, in soil with and without organic matter. Revista Árvore. 2016;40:455-64.

Samôr OJM, Carneiro JGA, Barroso DG, Leles PSS. Qualidade de mudas de angico e sesbânia, produzidas em diferentes recipientes e substratos. Revista Árvore 2002;26:209-15.

Santos LCR, Costa E, Leal PAM, Nardelli EMV, Souza GSA. Ambientes protegidos e substratos com doses de composto orgânico comercial e solo na formação de mudas de jatobazeiro em Aquidauana-MS. Engenharia Agrícola. 2011;31:249-59.

Sentelhas PC, Folegatti MV. Class-A pan coefficients $(\mathrm{Kp})$ to estimate daily reference evapotranspiration (ETo). Revista Brasileira de Engenharia Agrícola e Ambiental. 2003;7:111-5.

Silva CA, Dourado Neto D, Silva CJ, Freitas CA. Development of Hymenaea courbaril seedlings in function of containers and irrigation blades. Revista Árvore. 2016;40:487-98.

Silva EC, Nogueira RJMC. Crescimento de quatro espécies lenhosas cultivadas sob estresse hídrico em casa de vegetação. Revista Ceres. 2003;50:203-17.

Silva MAV, Nogueira RJMC, Oliveira AFM, Santos VF. Resposta estomática e produção de 
matéria seca em plantas de aroeira submetidas a diferentes regimes hídricos. Revista Árvore. 2008;32:335-44.

Silvestre WVD, Pinheiro HA, Souza RORM, Palheta LF. Morphological and physiological responses of açaí seedlings subjected to different watering regimes. Revista Brasileira de Engenharia Agrícola e Ambiental. 2016;20:364-71.

Vallone HS, Guimarães RJ, Mendes ANGM, Souza CAS, Cunha RL, Dias FP. Diferentes recipientes e substratos na produção de mudas de cafeeiros. Ciência e Agrotecnologia. 2010;34:55-60. 